\title{
Development and physical evaluation of Maytenus ilicifolia effervescent granules using factorial design
}

\author{
Marcilio Sérgio Soares da Cunha-Filho ${ }^{1, *}$, Pricila Castilho Gustmann², Felipe Sanches Garcia ${ }^{2}$, \\ Eliana Martins Lima ${ }^{3}$, Lívia Cristina Lira de Sá-Barreto ${ }^{4}$
}

\author{
${ }^{1}$ Faculty of Health Sciences, University of Brasilia, Brasilia, DF, Brazil, ${ }^{2}$ Institute of Health Sciences, Federal University \\ of Mato Grosso, Sinop, MT, Brazil, ${ }^{3}$ Faculty of Pharmacy, Federal University of Goiás, Goiânia, GO, Brazil, ${ }^{4}$ Faculty of \\ Ceilândia, Campus de Ceilândia, University of Brasília, Brasilia, DF, Brazil
}

\begin{abstract}
The medicinal plant Maytenus ilicifolia is a commonly used phytomedicine for the treatment of gastritis. The high dose required and low density of these extracts make necessary a daily intake of several capsules, hindering adherence to the medication. The purpose of this work was to develop a suitable dosage form for the administration of Maytenus ilicifolia using effervescent granules. A $2^{3}$ factorial design was used to study the physical characteristics of the granules (particle size distribution, repose angle, Carr index, scanning electron microscopy and disintegration time). Moisture stability was also determined. According to the experimental design, granule size is the most important factor in determining the flow characteristics of effervescent granules. In turn, the disintegration time is controlled by the content of sodium bicarbonate present in the effervescent mixture as well as the granule size. The stability of formulations when exposed to moisture is strongly influenced by the percentage of effervescent mixture present in the vegetal granules. Precautions in handling and storage should be taken to ensure the stability of these preparations. The effervescent granules produced from Maytenus ilicifolia met the pharmacopoeial quality parameters, with appropriate mechanical and physical characteristics and proved to be a promising vehicle for plant extracts.
\end{abstract}

Uniterms: Maytenus ilicifolia/pharmacognosy. Maytenus ilicifolia/Effervescent granules. Effervescent granules/physical characteristics/factorial design. Effervescent granules/water sorption behavior. Plant extracts/administration vehicle.

A planta medicinal Maytenus ilicifolia é comumente empregada como fitoterápico no tratamento da gastrite. As elevadas doses requeridas e a baixa densidade dos extratos dessa planta levam à ingestão diária de várias cápsulas do medicamento, dificultando a adesão ao tratamento. A proposta desse trabalho foi desenvolver uma forma farmacêutica adequada para administração de Maytenus ilicifolia usando granulados efervescentes. Um desenho fatorial $2^{3}$ foi empregado para estudar as características físicas dos granulados (distribuição dos tamanhos de partícula, ângulo de repouso, índice de Carr, microscopia eletrônica de varredura e tempo de desintegração). A higroscopicidade das preparações também foi estudada. De acordo com o desenho experimental, o tamanho de partícula é o fator mais importante para a determinação das características de fluxo dos granulados efervescentes. Em contrapartida, o tempo de desintegração é controlado pelo conteúdo de bicarbonato de sódio presente na mistura efervescente, assim como pelo tamanho do granulado. A estabilidade das formulações quando expostas à umidade é fortemente influenciada pelo percentual de mistura efervescente presente nos granulados. Precauções de manipulação e armazenamento devem ser tomadas para garantir a estabilidade dessas preparações. Os granulados efervescentes produzidos com Maytenus ilicifolia cumprem os requisitos farmacopeicos de qualidade, com adequadas características físicas e mecânicas, provando ser um veículo promissor para extratos vegetais.

Unitermos: Maytenus ilicifolia/farmacognosia. Maytenus ilicifolia/granulados efervescentes. Granulados efervescentes/características físicas/planejamento fatorial. Granulados efervescentes/ higroscopicidade. Extratos vegetais/veículo de administração.

\footnotetext{
*Correspondence: M. S. S. Cunha-Filho. Faculdade de Ciências da Saúde, Universidade de Brasília, Campus Universitário Darcy Ribeiro, 70910-900 - Brasília - DF, Brasil. Tel. +55 6131071990; Fax. +55 6131071990. E-mail: marciliocunha@unb.br
} 


\section{INTRODUCTION}

During the past few decades, the usage of phytomedicine has increased even in industrialized countries as an alternative to synthetic medicines, which are considered more expensive and harmful to the body (WHO, 2007). Despite the great potential of medicinal plants, there is a shortage of scientific literature on this subject, especially on their preparation and formulation (Alves et al., 2011).

Maytenus ilicifolia (Schrad.) Planch. Celastraceae is a plant originating from South America with wide therapeutic applications for treating gastritis and stomach ulcers, mainly due to the presence of polyphenols in the leaf extract (Baggio et al., 2007).

Among the substances most frequently found in this plant and that may account for its therapeutic properties stand out the terpenoids maitenin and tringenona, the triterpenes friedelanol and friedelin and the tannin epicatechin. Some glycolipids, such as monogalactosildiacilglicerol and digalactosyldiacylglycerol, and the alkaloids maiteina, maitanprina and maitensina also have been isolated and identified (Mossi et al., 2004; Santos-Oliveira et al., 2009).

Despite these therapeutic benefits, the high dose of solids required for the administration of these extracts and their low density make it necessary to take numerous hard gelatin capsules per dose, which can reach up to 9 capsules per day. Therapeutic compliance is even more difficult for elderly patients, who have difficulty swallowing (Hill et al., 2009).

Effervescent preparations are therefore interesting alternatives for the pharmaceutical administration of herbal extracts due to their ability to incorporate large amounts of material in a single dose. Additionally, they are easy to take, exhibit more stability than liquid dosage forms and offer the possibility to improve the absorption of the active ingredients due to prior dissolution (Maximiano et al., 2011). There are no commercial pharmaceutical preparations of Maytenus ilicifolia using effervescent vehicles available.

Effervescent preparations are very sensitive to moisture, which may compromise their chemical stability and promote a premature reaction releasing carbon dioxide. In this context, it is desirable to develop an optimum formulation that improves effervescent stability (Wells et al., 1997; Jacob et al., 2009).

The aim of this work was to obtain a suitable dosage form for the administration of dried extracts of Maytenus ilicifolia. For this, effervescent granules were developed, and the influence of the composition and manufacturing process on the physical and mechanical characteristics of the granules and their moisture stability were studied using a factorial design.

\section{MATERIAL AND METHODS}

\section{Material}

Dried leaf extract from Maytenus ilicifolia (Schrad.) Planch. Celastraceae, batch 33695, containing 3.5\% tannins was supplied by All Chemistry ${ }^{\circledR}$ (São Paulo, Brazil). Anhydrous citric acid, sodium bicarbonate and sodium carbonate were obtained from Natural Pharma ${ }^{\circledR}$ (São Paulo, Brazil), and lactose monohydrate was purchased from Henrifarma ${ }^{\circledR}$ (São Paulo, Brazil). All solvents were of analytical grade.

\section{Preparation of Maytenus ilicifolia effervescent granules}

Granules were prepared by wet granulation using Maytenus ilicifolia dried extract, lactose and an effervescent mixture formed by anhydrous citric acid, sodium bicarbonate and sodium carbonate. Different formulations were tested according to a factorial design. Mixtures of dry extract and excipients were blended manually for 20 min and wetted with absolute ethanol in a mortar. The samples were strained through selected sieves ( 1 and $2 \mathrm{~mm}$ ) as one of the factors studied in the experimental design. The extruded granules were dried in a circulating air oven at $37^{\circ} \mathrm{C}$ for $6 \mathrm{~h}$.

\section{Factorial experimental design}

Effervescent granules of Maytenus ilicifolia were made according to a complete $2^{3}$ factorial design. The factors studied were the effervescent mixture percentage in the granule $-X_{1}(20$ and $40 \%)$, the percentage of sodium bicarbonate in the effervescent mixture $-\mathrm{X}_{2}(10$ and $40 \%)$ and the sieve size used for granulation $-\mathrm{X}_{3}(1$ and $2 \mathrm{~mm})$. All the factors studied were independent of each other. The formulation compositions and the effervescent mixture compositions are given in Table I.

The responses evaluated were the disintegration time, the angle of repose, the Carr index and the percentage of water variation in the samples kept in a high relative humidity atmosphere.

The best fitting mathematical model was selected for each response. The model predictor equations were estimated by stepwise multiple regression analysis. Validation of the model was performed by analysis of variance with a significance level of 0.05 and by the 
TABLE I - Components used in the effervescent granules of Maytenus ilicifolia, the composition of the effervescent mixture and the sieve size used in the granulation

\begin{tabular}{|c|c|c|c|c|c|c|c|}
\hline \multirow[b]{2}{*}{ Formulation } & \multirow{2}{*}{$\begin{array}{c}\text { Dried extract } \\
(\%)\end{array}$} & \multirow[b]{2}{*}{$\begin{array}{l}\text { Effervescent } \\
\text { mixture (\%) }\end{array}$} & \multirow[b]{2}{*}{ Lactose $(\%)$} & \multicolumn{3}{|c|}{ Composition of effervescent mixture (\%) } & \multirow{2}{*}{$\begin{array}{l}\text { Sieve size } \\
\quad(\mathrm{mm})\end{array}$} \\
\hline & & & & citric acid & $\begin{array}{c}\text { sodium } \\
\text { bicarbonate }\end{array}$ & $\begin{array}{c}\text { sodium } \\
\text { carbonate }\end{array}$ & \\
\hline F1 & 50 & 20 & 30 & 50 & 40 & 10 & 2 \\
\hline $\mathrm{F} 2$ & 50 & 40 & 10 & 50 & 40 & 10 & 1 \\
\hline F3 & 50 & 20 & 30 & 50 & 10 & 40 & 1 \\
\hline F4 & 50 & 40 & 10 & 50 & 10 & 40 & 1 \\
\hline F5 & 50 & 20 & 30 & 50 & 40 & 10 & 1 \\
\hline F6 & 50 & 20 & 30 & 50 & 10 & 40 & 2 \\
\hline F7 & 50 & 40 & 10 & 50 & 40 & 10 & 2 \\
\hline F8 & 50 & 40 & 10 & 50 & 10 & 40 & 2 \\
\hline
\end{tabular}

coefficient of determination $\left(\mathrm{R}^{2}\right)$. Adequate precision (APrecision) was calculated as a signal-to-noise ratio relative to the associated error. A ratio greater than four was desirable. All statistical calculations and graphic plots were performed using the Design-Expert version 8 software (Minneapolis, MN, USA) (Anderson, Whitcomb, 2005; Souza et al., 2012).

\section{Physical-chemical characterization}

\section{Particle size analysis}

To determine the particle size distribution of the effervescent granules, a sieve analysis was performed using an Advantech Sonic Sifter (Advantech Manufacturing Inc., New Berlin, WI) fitted with sift pulse mode with $4 \mathrm{~mm}$ of amplitude. The linearization of the Gaussian particle size distribution was developed using probit statistical analysis. The mean cumulative particle size dates were converted into probit values using a probit spreadsheet. The particles' mean diameter and standard deviation were calculated from probit regression (Singh, Prakash, 2012).

\section{Scanning electron microscopy (SEM)}

Scanning electron micrographs were taken using a Jeol 840A microscope (Westmont, IL) operating at 15 $\mathrm{kV}$. Particles were fixed on a brass stub using a conductive double-sided adhesive tape and coated with gold under a vacuum.

\section{Flow property study}

The flow properties of Maytenus ilicifolia dried extracts and effervescent granules were studied by the angle of repose and the Carr index. The angle of repose was measured by the fixed funnel method using the internal angle subtended by the surface of a heap of powder against the plane that supports it. The Carr index was determined using bulk density and tap density values and was calculated using the equation below (Carr, 1982):

\section{Carr Index $=100 \times(\delta \mathrm{t}-\delta \mathrm{a}) / \delta \mathrm{t}$}

Where $\delta a$ is the bulk density of the freely settled material, and $\delta \mathrm{t}$ is the tapped density of the material obtained after cycles of 1.000 taps. All measurements were taken as 10 replicates.

\section{Disintegration time}

Approximately $1.6 \mathrm{~g}$ of each effervescent granule batch was placed in $250 \mathrm{~mL}$ of water at $25^{\circ} \mathrm{C}$. The granules were considered disintegrated when completely dispersed fragments were obtained and the liberation of gas stopped. 6 replicates of this experiment were performed according to the pharmacopeia (European Pharmacopoeia, 2007).

\section{Water sorption assay}

The hygroscopicity of the effervescent granules was compared with that of Maytenus ilicifolia dried extract using the experimental model described by Callahan (Callahan et al., 1982). The moisture sorption properties of $250 \mathrm{mg}$ samples were determined gravimetrically before and after storage at $25^{\circ} \mathrm{C}$ under conditions of various relative humidity $(0-90 \% \mathrm{RH})$ in hermetic systems for 7 days. The various RH conditions were achieved using saturated salt solutions as follow: $0 \%$ (silica gel); $8 \%$ (potassium hydroxide); 31\% (potassium fluoride); $43 \%$ (potassium carbonate); 69\% (potassium iodide); and $84 \%$ (potassium chloride) (Greenspan, 1977). The water sorption behavior was evaluated from the increase or decrease in weight of samples at each storage time and was expressed as the moisture increase per starting weight. The assay was performed in triplicate. 


\section{RESULTS AND DISCUSSION}

\section{Physical-chemical characterization}

Routine experimental studies involve the use of one factor at time, while keeping other factors constant. This type of strategy offers limited and sometimes inaccurate information about the impact of the variables involved in the study. Factorial design allows a well-planned experiment, which yields more information for less effort. This strategy enables the identification of the individual contribution of each factor and the possible interactions among them (Kulthe et al., 2013).

A $2^{3}$ factorial design was used in this study to assess the feasibility of obtaining Maytenus ilicifolia effervescent granules and to identify the most important factors involved in the mechanical and physical properties of the formulations. In this two-by-two-by-two experimental design, all the possible combinations of three factors and two levels were studied, giving rise to eight different formulations (Table I). Due to the characteristics of the formulations, it was not necessary use binding agents.

The experimental factors and their ranges were selected from previous tests. We studied variations in the effervescent mixture percentage $\left(\mathrm{X}_{1}\right)$, the percentage of sodium bicarbonate in the effervescent granules $\left(\mathrm{X}_{2}\right)$, and the size of the granules through their extrusion in different sieves $\left(\mathrm{X}_{3}\right)$. Factorial design allows the evaluation of the effects of different factors and their interactions. The responses were used to generate predictive equations for the dependent variables.

Granules with a 2mm sieve size (F1, F6, F7 and F8) fitted to a normal logarithm particle size distribution with a high degree of asymmetry in the smaller values of particle size. Moreover, granules produced with a $1 \mathrm{~mm}$ sieve size (F2, F3, F4 and F5) fitted to a normal distribution of particle size with a compact profile (Figure 1). The values for the mean particle size and fine powder percentage of the formulations are listed in Table II. In this study, it was considered fine powder, materials with particle size in the range of 125-180 $\mu \mathrm{m}$ (British Pharmacopoeia, 2012).

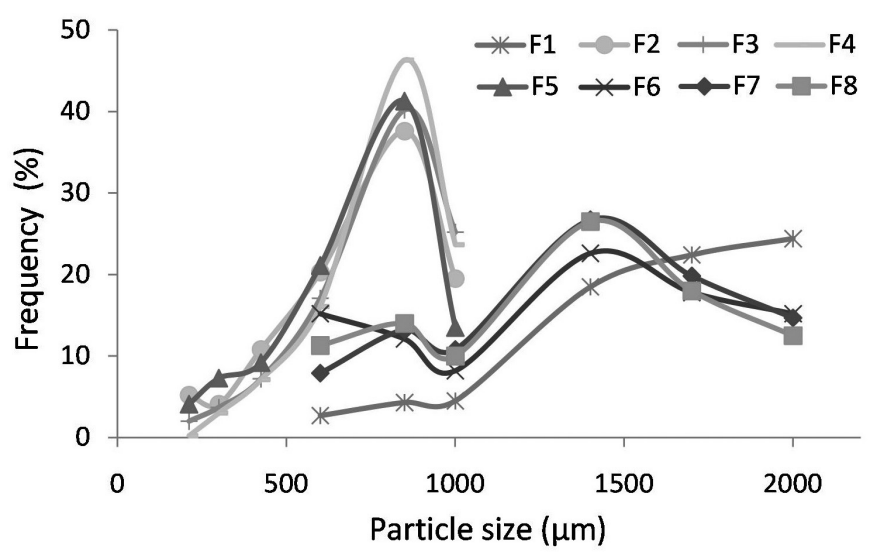

FIGURE 1 - Particle size distribution of Maytenus ilicifolia formulations of effervescent granules (F1, F2, F3, F4, F5, F6, $\mathrm{F} 7$ and F8) obtained from the factorial design using sonic sifter.

The high percentage of fine powder obtained in formulation F6 (Table II), above 10\%, may be related to the high concentration of lactose in this formulation and its low binding property. However, as can be observed in the following tests, this result does not appear to interfere with flow parameters. As described in the literature, the presence of fine powders in certain amount has been shown to improve the flowability of materials. Fines act lubricating of granules, reducing interparticle adhesion forces (Tomas et al., 2009).

The mean particle size of effervescent granules (Table II) calculated from the distributions explains the rheological behavior of the formulations, as discussed below.

The results of the rheological parameters assessed (Carr index and angle of repose), as well as the disintegration time and water absorption in high relative humidity, are compiled in Table III.

As might be expected, the dried extract of Maytenus

TABLE II - Mean particle size of Maytenus ilicifolia effervescent granules.

\begin{tabular}{lcccc}
\hline Formulation & Distribution & Mean particle size $(\boldsymbol{\mu m})$ & Standard deviation & Fine Powder $(\%)$ \\
\hline F1 & Log Normal & 1982.1 & 625.0 & 2.7 \\
F2 & Normal & 816.0 & 294.1 & 5.2 \\
F3 & Normal & 893.9 & 312.5 & 2.0 \\
F4 & Normal & 917.1 & 294.1 & 2.0 \\
F5 & Normal & 813.1 & 277.8 & 4.1 \\
F6 & Log Normal & 1531.7 & 555.6 & 15.2 \\
F7 & Log Normal & 1554.3 & 500.0 & 7.9 \\
F8 & Log Normal & 1546.4 & 526.3 & 9.4 \\
\hline
\end{tabular}


TABLE III - Physical and mechanical properties of the dried extract of Maytenus ilicifolia and its effervescent granules with the corresponding predictive equation together with the validation parameters of the model

\begin{tabular}{|c|c|c|c|c|}
\hline Sample & Carr index (\%) & Angle of repose $\left(^{\circ}\right)$ & Disintegration time (s) & $\begin{array}{l}\text { Water absorption } \\
(\%) \text { in high relative } \\
\text { humidity }\end{array}$ \\
\hline Dried extract & $37.3 \pm 2.0$ & $54.4 \pm 3.9$ & - & $19.9 \pm 1.0$ \\
\hline F1 & $2.5 \pm 1.7$ & $35.0 \pm 2.2$ & $108.2 \pm 9.0$ & $22.6 \pm 3.5$ \\
\hline F2 & $3.0 \pm 1.7$ & $36.0 \pm 1.9$ & $85.2 \pm 11.0$ & $28.7 \pm 5.1$ \\
\hline F3 & $4.3 \pm 2.0$ & $37.4 \pm 2.5$ & $115.7 \pm 7.9$ & $26.8 \pm 4.3$ \\
\hline F4 & $4.8 \pm 1.0$ & $36.5 \pm 2.3$ & $115.5 \pm 14.2$ & $25.1 \pm 1.8$ \\
\hline F5 & $7.7 \pm 2.3$ & $39.8 \pm 5.5$ & $80.3 \pm 3.7$ & $23.7 \pm 2.5$ \\
\hline F6 & $4.5 \pm 2.1$ & $36.9 \pm 2.5$ & $134.5 \pm 7.8$ & $22.9 \pm 2.6$ \\
\hline F7 & $4.5 \pm 2.2$ & $37.8 \pm 1.8$ & $120.5 \pm 17.5$ & $35.4 \pm 0.4$ \\
\hline F8 & $2.8 \pm 1.0$ & $37.7 \pm 4.4$ & $118.5 \pm 17.6$ & $32.6 \pm 3.6$ \\
\hline Predictive equation & $\begin{array}{c}=+12.6 \\
-0.22 \cdot X_{1} \\
+0.03 \cdot X_{2} \\
-4.8 \cdot X_{3} \\
+0.1 \cdot X_{1} \cdot X_{3}\end{array}$ & $\begin{array}{c}=+33.3 \\
+0.12 \cdot \mathrm{X}_{1} \\
+1.1 \cdot \mathrm{X}_{2} \\
-3.2 \cdot \mathrm{X}_{3} \\
-0.03 \cdot \mathrm{X}_{1} \cdot \mathrm{X}_{2} \\
-0.73 \cdot \mathrm{X}_{2} \mathrm{X}_{3} \\
-0.1 \cdot \mathrm{X}_{1} \mathrm{X}_{3} \\
+0.02 \cdot \mathrm{X}_{1} \mathrm{X}_{2} \cdot \mathrm{X}_{3}\end{array}$ & $\begin{array}{l}=+122.1 \\
+0.01 \cdot X_{1} \\
-3.6 \cdot X_{2} \\
+4.0 \cdot X_{3} \\
+1.4 \cdot X_{2} \cdot X_{3}\end{array}$ & $\begin{array}{c}=+13.4 \\
+0.32 \cdot X_{1} \\
+0.03 \cdot X_{2} \\
+2.3 \cdot X_{3}\end{array}$ \\
\hline$F$ & 3.14 & 2.29 & 19.41 & 5.51 \\
\hline APrecision & 4.45 & 4.99 & 10.63 & 5.61 \\
\hline
\end{tabular}

ilicifolia displayed very poor flow properties (Table III) (Alves et al., 2011). In contrast, the effervescent granules exhibited good flowability results, with only minor differences between the formulations.

The predictive equations clearly demonstrated the importance of the granule size for rheological parameters (Table III). The statistical analysis shows that $\mathrm{X}_{3}$ is the factor that most prominently impacts the flow characteristics of Maytenus ilicifolia granules. The increase in granule size results in a better flowability (negative term with a high coefficient in the predictive equation for both the Carr index and the angle of repose). Some interactions between factors are placed as significant terms in the equation, although they only have a secondary impact on those responses.

The contour plots drawn from flow responses show a nearly linear relationship between sieve size and the other factors studied (Figure 2).

Among the formulations studied, F5 displayed the worst flow results (Table III). This can be explained by its granulometry, as these granules exhibit the smallest mean particle size (Table II) and an irregular shape, as
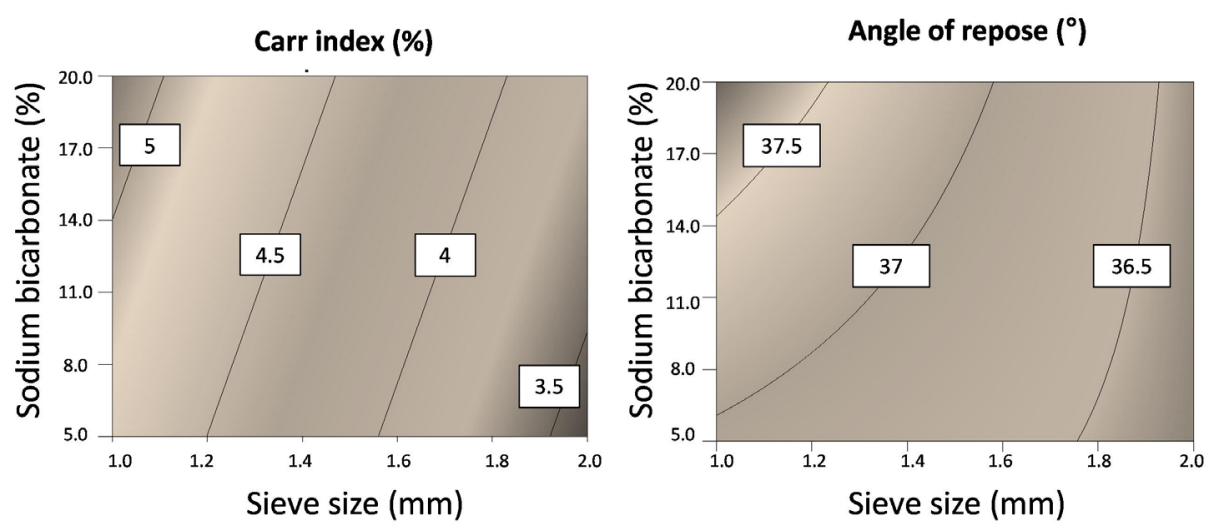

FIGURE 2 - Contour diagrams of Maytenus ilicifolia effervescent granules developed according to factorial design for the Carr index and the angle of repose. Each contour represents a constant response factor. 
seen in SEM photomicrography (Figure 3). In contrast, formulation F1 displayed the best flow characteristics,
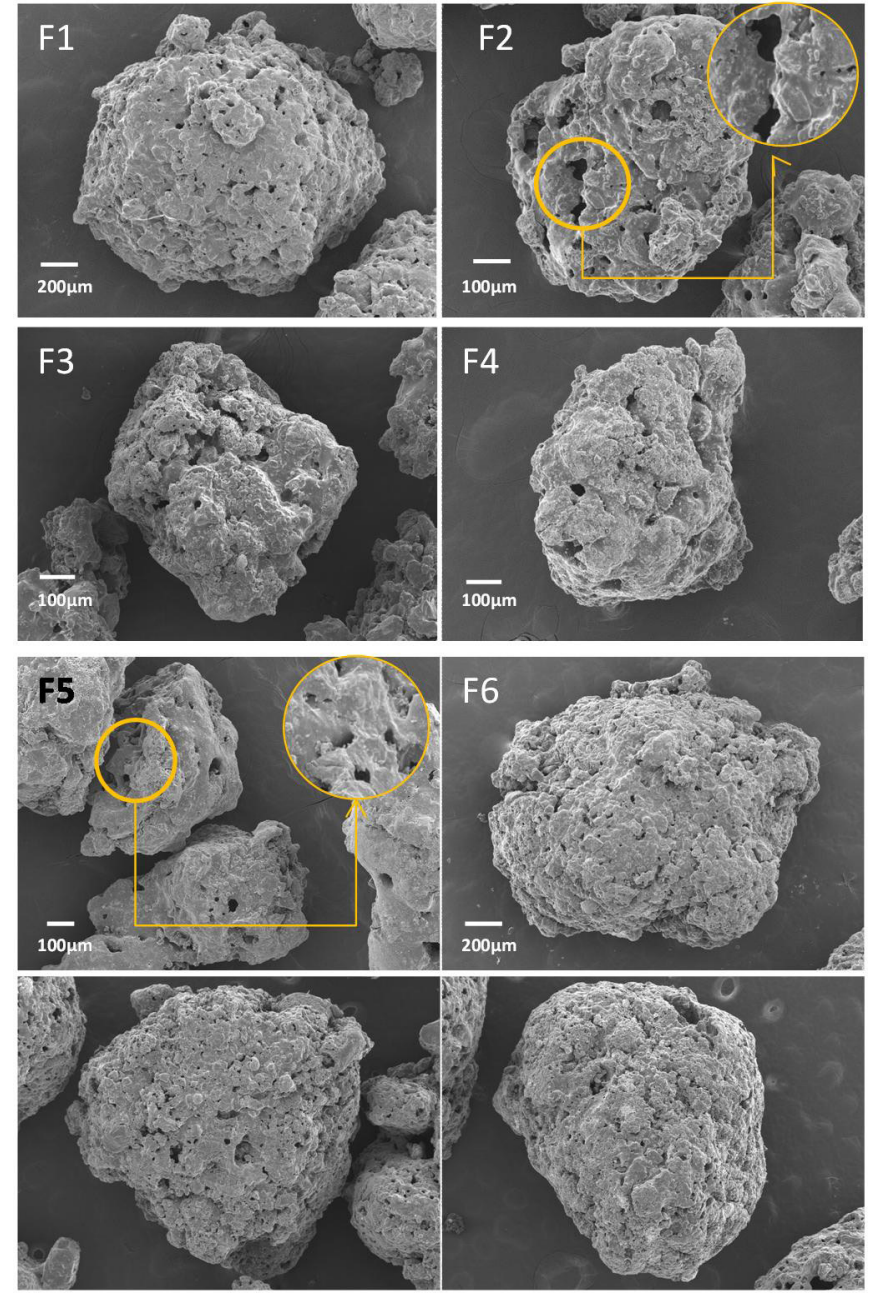

FIGURE 3 - Scanning electron micrographs of Maytenus ilicifolia formulations of effervescent granules (F1, F2, F3, F4, F5, F6, F7 and F8) obtained from the factorial design. The pores of F2 and F5 are shown in detail.

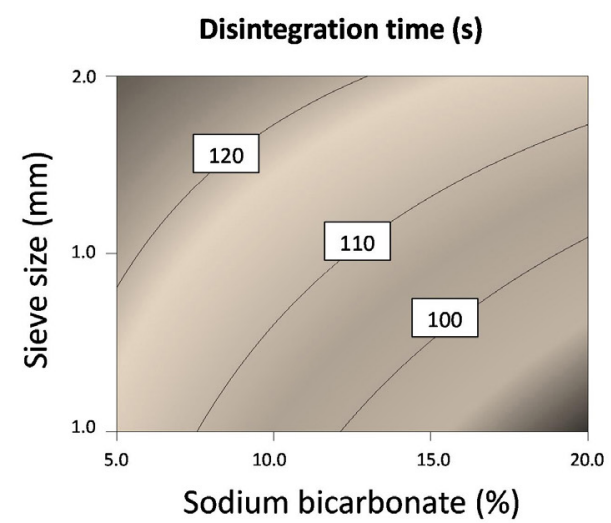

which can be explained by its large mean particle size (Table II) and its regular spherical shape, which reduces particle cohesion and facilitates flow (Figure 3).

The effervescent granules of Maytenus ilicifolia obtained for all formulations were found to obey the pharmacopoeial requirements regarding disintegration time (Table III). Based on the predictive equation (Table III), this response was strongly influenced by the percentage of sodium bicarbonate in the effervescent mixture $\left(\mathrm{X}_{2}\right)$ and by the particle size $\left(\mathrm{X}_{3}\right)$. The interaction between these factors was statistically significant with a positive term, indicating that both factors combined to promote an increase in the disintegration time.

A high concentration of sodium bicarbonate reduces the disintegration time, favoring effervescence (negative term in the equation). Furthermore, the particle size increases the disintegration time, making effervescence slow (positive term of the equation). The formulations prepared with the $2 \mathrm{~mm}$ sieve displayed a disintegration time of $120 \mathrm{~s}$, whereas the $1 \mathrm{~mm}$ extruded granules disintegrated in just 80 s.

The manner in which factors $\mathrm{X}_{2}$ and $\mathrm{X}_{3}$ are related in determining the disintegration time is shown in the contour plots of Figure 4.

Surprisingly, according to the factorial design statistical analysis, the disintegration time was not influenced by the effervescent mixture percentage in the granule $\left(\mathrm{X}_{1}\right)$. The results can be explained by the range of effervescent mixtures selected (20-40\%). Within this range, the effervescence reaction occurs with approximately the same intensity.

As seen in Tables II and III, fast disintegration times were achieved with formulations of a smaller particle size (F2 and F5). These results show the importance of the contact surface for this parameter. Scanning electron micrographs support this thesis, revealing a rather

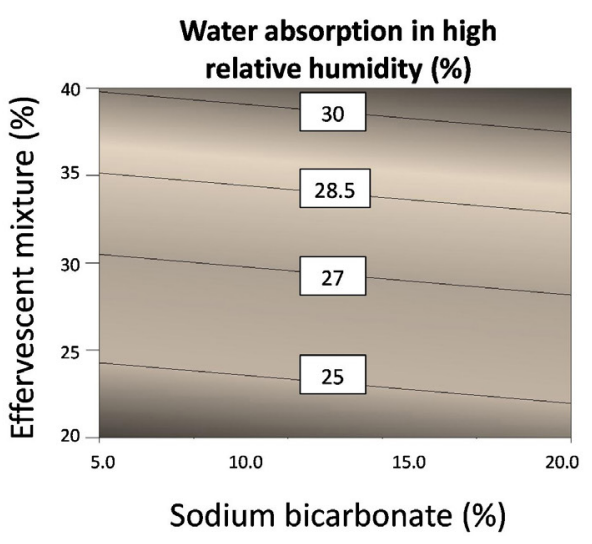

FIGURE 4 - Contour diagrams of Maytenus ilicifolia effervescent granules developed according to factorial design for disintegration time and water absorption in high relative humidity. Each contour represents a constant response factor. 
porous surface of these granules compared with other formulations (Figure 3). The worst performance in this parameter was achieved by formulation F6 due to its high particle size (Table II) and its more compact surface, which hinders water penetration (Figure 3 ).

\section{Water sorption assay}

The sorption isotherms were drawn by determining the equilibrium moisture content for the dried extract and the developed formulations at different relative humidities after 1 week at $25^{\circ} \mathrm{C}$ (Figure 5).

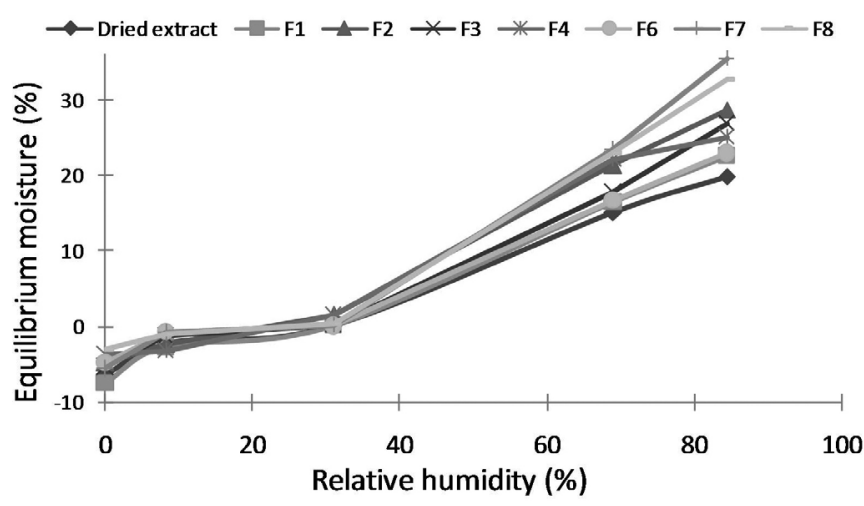

FIGURE 5 - Sorption isotherms of Maytenus ilicifolia dried extract and formulations of effervescent granules (F1, F2, F3, F4, F5, F6, F7 and F8) obtained from the factorial design.

The dried extract of Maytenus ilicifolia demonstrated a moderately hygroscopic profile according to the Callahan classification (Callahan et al., 1982), in agreement with other studies with vegetal materials (Alves et al., 2011; Souza et al., 2007).

The effervescent granules displayed an increase in this tendency. Formulations F7 and F8 are classified as very hygroscopic, whereas the rest of formulations are moderately hygroscopic.

Only the effervescent mixture percentage $\left(\mathrm{X}_{1}\right)$ showed a statistically significant effect on water absorption in high relative humidity (Table III). No interaction between the factors was observed. This result is in accordance with results in the literature that describe effervescent components as hygroscopic (Amela et al., 1996). The contour plots revealed that high amounts of effervescent mixture in the formulation increase the hygroscopicity of the granules, whereas the amount of bicarbonate in the granule does not play an important role (Figure 4). This result contradicts those described in the literature of the higher sensitivity of sodium bicarbonate to moisture compared with sodium carbonate, which is classified as non-hygroscopic (Rowe et al., 2009).

Granule formulations assemble components with high hygroscopic potential, which increases the sensitivity of these preparations to moisture, especially in environments with high relative humidity. This was particularly critical for formulations F7 and F8, which have $50 \%$ dried extracts and $40 \%$ effervescent components. Precautions for handling and storage should be taken to ensure the physical and chemical stability of these preparations.

\section{CONCLUSIONS}

Factorial design was demonstrated to be a useful method for the characterization of the effects of variables in the development of effervescent granules. According to the experimental design, granule size was the factor that had the most impact on the flow characteristics of effervescent granules. In turn, the disintegration time was controlled by the content of sodium bicarbonate present in the mixture as well as the granule size. The stability of developed formulations to moisture was strongly influenced by the percentage of effervescent mixture present in the vegetal granules.

In conclusion, the effervescent granules produced from Maytenus ilicifolia met the pharmacopoeial quality parameters, with the appropriate mechanical and physical characteristics. The effervescent granules proved to be a promising vehicle for plant extracts due to their simplified processing, easy administration, rapid disintegration, good flow properties and low cost.

\section{ACKNOWLEDGMENT}

This work was funded by CNPq (Brazil) and by Department of Research and Postgraduate of Brasilia University (Brazil). The authors also thank the support of Electronic Microscopy Laboratory of Brasilia University (Brazil).

\section{REFERENCES}

ALVES, V.M.L.; SÁ-BARRETO, L.C.L.; SOUZA, G.H.B.; CUNHA-FILHO, M.S.S. Co-processed extracts of Cassia angustifolia and Maytenus ilicifolia for production of high load tablets. Rev. Bras. Farmacogn., v.21, p.510-517, 2011.

AMELA, J.; SALAZAR, R.; CEMELI, J. Effervescent tablets of ascorbic acid. I Phisical study of the possible components to be used. Drug Dev. Ind. Pharm., v.22, p.407-416, 1996. 
ANDERSON, M.J.; WHITCOMB, P.J. RSM Simplified: optimizing processes using response surface methods for design of experiments. 1.ed. New York: Productivity Press, 2005. $292 \mathrm{p}$.

BAGGIO, C.H.; FREITAS, C.S.; OTOFUJI, G.M.; CIPRIANI, T.R.; SOUZA, L.M.; SASSAKI, G.L.; IACOMINI, M.; MARQUESA, M.C.A.; MESIA-VELAC, S. Flavonoidrich fraction of Maytenus ilicifolia Mart. ex. Reiss protects the gastric mucosa of rodents through inhibition of both $\mathrm{H}+, \mathrm{K}+$-ATPase activity and formation of nitric oxide. $J$. Ethnopharmacol., v.113, p.433-440, 2007.

BRITISH Pharmacopoeia. Appendix XVII A. Particle size of powders. v.V, 2012.

CALLAHAN, J.C.; CLEARY, G.W., ELEFANT, M.; KAPLAN, G.; KENSLER, T.; NASH, R.A. Equilibrium moisture content of pharmaceutical excipients. Drug Dev. Ind. Pharm., v.8, p.355-369, 1982.

CARR, R.L. Evaluation of flow properties of solids. Chem. Eng. $J .$, v.72, p.163-168, 1982.

EUROPEAN Pharmacopoeia. 6.ed. Council of Europe European, 2007. p.225-226.

HILL, S.W.; VARKER, A.S.; KARLAGE, K.; MYRDAL, P.B. Analysis of drug content and weight uniformity for HalfTablets of 6 commonly split medications. J. Manag. Care Pharm., v.15, p.253-261, 2009.

GREENSPAN, L. Humidity fixed points of binary saturated aqueous solutions. J. Res. Natl. Bur. Stand., v.81A, p.8996, 1977.

JACOB, S.; SHIRWAIKAR, A.; NAIR, A. Preparation and evaluation of fast-disintegrating effervescent tablets of glibenclamide. Drug Dev. Ind. Pharm., v.35, p.321-328, 2009.

KULTHE, S.S.; BAHEKAR, J.K.; GODHANI, C.C.; CHOUDHARI, Y.M.; INAMDAR, N.N.; MOURYA, V.K. Modulated release of 5-fluorouracil from $\mathrm{pH}$-sensitive and colon targeted pellets: an industrially feasible approach. Drug Dev. Ind. Pharm., v.39, p.138-145, 2013.

MAXIMIANO, F.P.; COSTA, G.H.Y.; SÁ-BARRETO, L.C.L.; BAHIA, M.T.; CUNHA-FILHO, M.S.S. Development of effervescent tablets containing benznidazole complexed with cyclodextrin. J. Pharm. Pharmacol., v.63, p.786-793, 2011.
MOSSI, A.J.; CANSIAN, R.L.; CARVALHO, A.Z.; DARIVA, C.; OLIVEIRA, J.V.; MAZUTTI, M.; FILHO, I.N.; ECHEVERRIGARAY, S. Extraction and characterization of volatile compounds in Maytenus ilicifolia using highpressure $\mathrm{CO}_{2}$. Fitoterapia, v.75, p.168-178, 2004.

ROWE, R.C.; SHESKEY, P.J.; QUINN, M.E. Handbook of Pharmaceutical Excipients, 6.ed. London: Pharmaceutical Press, 2009.

SANTOS-OLIVEIRA, R.; COULAUD-CUNHA, S.; COLAÇO, W. Review of Maytenus ilicifolia Mart. ex Reissek, Celastraceae. Contribution to the studies of pharmacological properties. Rev. Bras. Farmacogn., v.19, p.650-659, 2009.

SINGH, G.; PRAKASH, S. Lethal effects of Aspergillus niger against mosquitoes vector of Filaria, Malaria, and Dengue: a liquid mycoadulticide. Sci. World J., v.2012, p.1-5, 2012.

SOUZA, T.P.; MARTÍNEZ-PACHECO, R.; GÓMEZ-AMOZA, J.L.; PETROVICK, P.R. Eudragit E as excipient for production of granules and tablets from Phyllanthus niruri $\mathrm{L}$ spraydried extract. AAPS Pharm. Sci. Tech., v.8, p.E54-E60, 2007.

SOUZA, F.S.; PIROLLI, M.M.; DIEHL, E.E.; SONAGLIO, D. Study of the variables which influence the impregnation of globules, compressed tablets and tablet triturates used in homeopathy. Braz. J. Pharm. Sci., v.48, p.537-545, 2012.

TOMAS, J.; KLEINSCHMIDT, S. Improvement of flowability of fine cohesive powders by flow additives. Chem. Eng. Technol., v.32, p.1470-1483, 2009.

WELLS, M.L.; WOOD, D.L.; SANFTLEBEN, R.; SHAW, K.; HOTTOVY, J.; WEBER, T.; GEOFFROY, J.M.; ALKIRE, T.G.; EMPTAGE, M.R.; SARABIA, R. Potassium carbonate as a desiccant in effervescent tablets. Int. $J$. Pharm., v.152, p.227-235, 1997.

WORLD HEALTH ORGANIZATION. Guidelines for assessing quality of herbal medicines with reference to contaminants and residues. Switzerland: WHO, 2007. Available at: www. who.int Accessed on: March,12 $2^{\text {th }}, 2014$.

Received for publication on $26^{\text {th }}$ February 2013 Accepted for publication on $20^{\text {th }}$ January 2014 